\title{
Chemical Attributes of a Typic Acrudox Soil on Marandu Palisade Grass under Rotational Stocking, Liming and Nitrogen Fertilisation
}

\author{
Valdinei T. Paulino*, Erika M. C. Teixeira, Keila M. R. Duarte, Marcia A. C. Lucena \\ Institute of Animal Sciences and Pastures, Nova Odessa, Brazil \\ Email: "paulino@iz.sp.gov.br, keiladuarte@globo.com, lucena@iz.sp.gov.br, eritalia@hotmail.com
}

Received 10 January 2014; revised 27 February 2014; accepted 13 March 2014

Copyright $@ 2014$ by authors and Scientific Research Publishing Inc.

This work is licensed under the Creative Commons Attribution International License (CC BY).

http://creativecommons.org/licenses/by/4.0/

(c) (i) Open Access

\begin{abstract}
Urochloa brizantha (synonymous of Brachiaria) is the most spread species of grass in the tropical world, primarily in regions with acid and low fertility soils. This study was conducted to investigate changes in the soil chemical properties of a Typical Acrudox submitted to a strategy of grazing with rotational stocking, liming and nitrogen fertilisation. Treatments involved combinations of two pre-grazing heights $\left(25\right.$ and $35 \mathrm{~cm}$ ) with two rates of nitrogen (50 and $\left.200 \mathrm{~kg}^{\circ} \mathrm{ha}^{-1} \cdot \mathrm{year}^{-1}\right)$. All combinations received lime, $P$ and $K$ fertilization and an untreated control group was allocated according to a complete randomised block design, five replications. Soil sampling was done in layers of $0-5,5-10,10-20,20-30$ and $30-40 \mathrm{~cm}$ deep in pastures of $U$. brizantha Marandu (Palisade grass). The samples were analysed for $\mathrm{pH}, \mathrm{H}^{+}+\mathrm{Al}^{3+}$, soil organic matter (SOM), $\mathrm{P}, \mathrm{K}^{+}, \mathrm{Ca}^{2+}$, $\mathrm{Mg}^{2+}$, exchangeable and calculated $\mathrm{CEC}, \mathrm{BS} \%$ and aluminium saturation. Liming and fertilisation improve the soil fertility. The highest organic matter contents were obtained for the $0-5 \mathrm{~cm}$ layer, with a nitrogen fertilisation of $200 \mathrm{~kg} \cdot \mathrm{N} \cdot \mathrm{ha}^{-1}$. The management practice for the pre-grazing height of $25 \mathrm{~cm}$, regardless of the nitrogen, is the best strategy for soil quality and livestock production.
\end{abstract}

\section{Keywords}

Grazing Heights; Rotational Stockings; Soil Fertility; Urochloa brizantha

\section{Introduction}

Brazil's extensive system of beef production relies on the use of forage plants adapted to different climate and soil conditions. Grasslands occupy about 174 million hectares of Brazilian territory, and approximately $60 \%$ of

Corresponding author.

How to cite this paper: Paulino, V.T., Teixeira, E.M.C., Duarte, K.M.R. and Lucena, M.A.C. (2014) Chemical Attributes of a Typic Acrudox Soil on Marandu Palisade Grass under Rotational Stocking, Liming and Nitrogen Fertilisation. American Journal of Plant Sciences, 5, 1039-1048. http://dx.doi.org/10.4236/ajps.2014.57116 
them experience some level of degradation. The livestock sector uses forages as its main source of food for cattle, $70 \%$ of which belong to the genus Urochloa (before classified as Brachiaria). Urochloa brizantha (Hochst. ex A. Rich.) cv. Marandu (Marandu grass) is now very important in Brazil and is grown on 70 million hectares [1]. This grass is the principal diet for approximately $95 \%$ of animals slaughtered in Brazil, which has resulted in reductions in the production costs for the cattle industry in comparison to grain-based systems.

Pastures are primarily grown in Oxisol soils and are commonly exploited as extractive in agriculturally unfavourable soil, which is justified at least in part by the low productivity and profitability of beef cattle. Such production systems rarely use fertilisers, which, particularly in the maintenance phase of grassland, exacerbate the problem of the soil's low natural fertility.

These soils are mostly acid and deficient in phosphorus, and contain aluminium, which is toxic for plants. The greatest harm to plants in acid soils is caused by the presence of toxic amounts of $\mathrm{Al}$ and $\mathrm{Mn}$ and by lack of $\mathrm{Ca}$ and/or Mg. At low pH levels, soil P availability, organic matter and microorganism activity are also adversely affected but assume less importance because these problems can be overcome by applying larger amounts of those nutrients and N. Deficiencies of Ca and Mg are also solved by applying lime. The main problems in acid soils can then be summarised by the phytotoxicity of $\mathrm{Al}$ and $\mathrm{Mn}$.

The best yield is achieved when lime applications are combined with phosphate fertilisation in pasture systems [2]. There are many other approaches to increasing productivity per hectare, such as new grass cultivars, for example $U$. brizantha $\mathrm{x} U$. ruziziensis artificial hybrids, which are Al-resistant and tolerate high grazing pressures and enable higher stocking rates per hectare [3]. These technologies are innovative options for improving yield, with their basis in recovering P-use efficiency. There are additional yield-based or financial benefits that justify fertilisation at lower critical levels, such as those for P. Another important cause of low productivity in Brazilian pastures is nitrogen deficiency [4]. Studies have shown that the annual deficit of nitrogen in tropical grass pastures that are not fertilised ranges from 60 to $125 \mathrm{~kg} \cdot \mathrm{ha}^{-1}$ [5]. However, the potential of these soils is elevated if the limitations are corrected. Nitrogen is the primary nutrient to be supplied for properly recovering degraded pastures or preventing their degradation, which increases the biomass of the grassland and stocking rates [6] [7].

The grazing animal is an important tool in the nutrient cycle. Although it has been suggested that rotational grazing (as opposed to continuous grazing) can reduce camping effects, there is little evidence that increasing the frequency of rotational grazing there are some other benefits on the distribution of nutrients in paddocks [8]. Paddock subdivision, or rotational grazing, can improve the distribution of excreta. Although the distribution of nutrients across the farm is also unusual, it is most associated with regular patterns of stock movement. In this particular case, paddock subdivisions promote the regular distribution of nutrients. The stocking rates that consider the morpho-physiological characteristics of grasses enhance and improve the utilisation of the pasture. For Marandu grass in rotational grazing, it is recommended that the pre-grazing height (height of the pasture before grazing) should be $25 \mathrm{~cm}$ (equivalent to 95\% light interception by the canopy) and that the post-grazing height (height after grazing) around $15 \mathrm{~cm}$ [9].

This study aimed to evaluate the changes in soil chemical attributes of a Typic Acrudox soil that was submitted to rotational stocking grazing and a liming and a nitrogen fertilisation strategy in a pasture of Urochloa brizantha cv. Marandu.

\section{Materials and Methods}

\subsection{Study Site Description}

This study was carried out from 15 January 2009 to 15 March 2010 at the Institute of Animal Science and Pastures (IZ) at Nova Odessa, São Paulo State. The IZ's experimental area is located in Nova Odessa county, SP ( $22^{\circ} 42^{\prime} \mathrm{S}, 47^{\circ} 18^{\prime} \mathrm{W}$ and $528 \mathrm{~m}$ altitude). According to the Köppen system, the climate of this region is considered mesothermal humid with a subtropical dry winter and is classified as Cwa, with average temperatures below $18^{\circ} \mathrm{C}$ in the coldest months and above $22^{\circ} \mathrm{C}$ in warmer months. The average annual rainfall for the county is $1270 \mathrm{~mm}$ (30\% occurring from May to September). Pastures of Marandu palisade grass (Urochloa brizantha Hochst. Ex. A. Rich.) Webster cv. Marandu (Syn. Brachiaria brizantha cv. Marandu), cultivated in 1995 were kept under rotational grazing use in a soil classified as Typic Acrudox and composed of sand (49.5\%), clay (20.9\%) and loam (29.6\%). Before the experiment the soil had the following composition: organic matter (SOM) $=20 \mathrm{~g} / \mathrm{dm}^{3} ; \mathrm{P}=4 \mathrm{mg} / \mathrm{dm}^{3} ; \mathrm{pH}$ em $\mathrm{CaCl}_{2}=4.0 ; \mathrm{K}=1.9 ; \mathrm{Ca}=8.0 ; \mathrm{Mg}=3.0 ; \mathrm{H}+\mathrm{Al}=44 ; \mathrm{CEC}=57.0$ and base saturation $(B S)=22.8 \%$ and of sand $(50.1 \%)$, clay (20.5\%) and loam (29.4\%). 


\subsection{Treatments and Experimental Design}

The following systems were evaluated: a) untreated control of $U$. brizantha cv. Marandu (control—without liming and $\mathrm{N}$ fertilisation); b) improved pastures (U. brizantha cv. Marandu) in which previous grazing was subjected to rotational grazing under the grazing management strategy and the use of nitrogen fertiliser.

Treatments corresponding to combinations between two pre-grazing heights (25 and $35 \mathrm{~cm})$ and two levels of nitrogen application (50 and $200 \mathrm{~kg} \cdot \mathrm{ha}^{-1} \cdot \mathrm{year}^{-1}$ ) (named as 25/50; 25/200; 35/50 and 35/200) all then receiving lime and an untreated control (without $\mathrm{N}$ and liming) were allocated into experimental units according to a complete randomised block design, with four replications.

Each experimental unit was comprised of six 0.5 ha paddocks that were managed as farmlets, which total of 4 ha. Each of the 20 units received three steers Nelore growing between 18 to 24 months old and an average body weight of $327 \mathrm{~kg}$, with a variable number of stocking rate adjustments.

Dolomitic limestone (containing 26.6\% $\mathrm{CaO}$ and $19.1 \% \mathrm{MgO}$ and relative power of total neutralization PRNT $=90 \%$ ) was applied as top dressing on pasture and without incorporation in December 2008. Lime was applied to increase the rate of base saturation to $50 \%$ in pastures of Marandu grass implanted at a using a dose of $1.0 \mathrm{t}^{\mathrm{h}} \mathrm{ha}^{-1}$, following the recommendation of Werner et al. (1996) [10]. The pastures were fertilized with phosphorus, potassium and nitrogen using NPK formulations, with the use of 25 and $100 \mathrm{~kg} \cdot \mathrm{ha}^{-1}$ of $\mathrm{P}_{2} \mathrm{O}_{5}$ and $\mathrm{K}_{2} \mathrm{O}$, respectively.

The experiment was conducted over two rainy seasons with application of 50 and $200 \mathrm{~kg} \mathrm{~N}$ in each period. During the first summer, in January 2009, it was made to broadcast fertilizer (50 kg.ha ${ }^{-1}$ ), urea and ammonium nitrate in all treatments with N. In February and March 2009, after leaving the animals in each paddock, it was performed over two split applications $\left(75 \mathrm{~kg} \cdot \mathrm{ha}^{-1}\right)$ in the treatments with $200 \mathrm{~kg} \cdot \mathrm{ha}^{-1} \cdot \mathrm{N}$. In the rainy season 2009/2010, the nitrogen fertilization was carried out in November/December $\left(50 \mathrm{~kg} \cdot \mathrm{ha}^{-1}\right)$, and $150 \mathrm{~kg} \cdot \mathrm{ha}^{-1} \mathrm{for}$

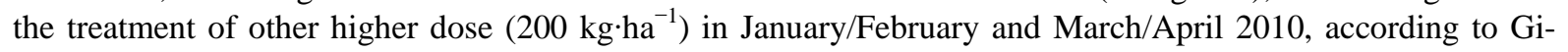
menes et al. (2011) [11].

Treatments corresponding to combinations between two pre-grazing heights (25 and $35 \mathrm{~cm}$ ) and two levels of nitrogen application (50 and $200 \mathrm{~kg} \cdot \mathrm{ha}^{-1} \cdot \mathrm{year}^{-1}$ ) all receiving lime and an untreated control were allocated to experimental units according to a complete randomised block design, with five replications. Each experimental unit was comprised of six 0.5 ha paddocks that were managed as farmlets. Steers used were growing Nelore between 18 to 24 months old and an average body weight of $327 \mathrm{~kg}$. Adjustments in stocking rate (animal $\cdot \mathrm{ha}^{-1}$ ) were performed according to the need of maintaining the a pre-grazing height for each treatment of 25 or $35 \mathrm{~cm}$ for all paddocks, and the target of the post-grazing height (residue) was $15 \mathrm{~cm}$ for all treatments. The heights of 25 or $35 \mathrm{~cm}$ correspond to $95 \%$ - 100\% of the incident light intercepted by the canopy in other experiments with the same forage plant [12]. The monitoring time for entrance of the steers in the paddocks was made by periodic assessments of the canopy height using the meter stick (sward stick) [13] along lines of pre-defined transects with 100 readings per paddock. Each farmlet received three Nelore steers (initial body weight of $327 \mathrm{~kg}$ ) as test animals for measuring body weight gain plus a variable number of additional steers to adjust stocking for individual paddocks. The planed target post-grazing height was $15 \mathrm{~cm}$, but it fluctuated above this to contribute to maintaining the target pre-grazing heights. In comparison to those managed at $35 \mathrm{~cm}$, farmlets managed at a 25 cm pre-grazing height showed a larger amount of grazing, period's shorter grazing intervals and occupation periods of the paddocks.

Soil sampling was conducted in April 2010. The samples were collected in trenches up to $40 \mathrm{~cm}$ deep in each area, and sectioned into layers (0 - 5; 50 - 10; 10 - 20; 20 - 30; 30 - $40 \mathrm{~cm})$.

Collected soil samples were air-dried and submitted to sieve loosening $(2 \mathrm{~mm})$ before analysed. A portion of the sample was ground and sieved through 60 mesh sieves $(0.250 \mathrm{~mm})$ and sent to the Laboratory of Environmental Biogeochemistry (CENA-USP) to determine the organic carbon content. The other samples were analysed in the Soil Analysis Laboratory of the Department of Soils and Plant Nutrition (ESALQ-USP). The soil $\mathrm{pH}$ was determined in $\mathrm{CaCl}_{2} 0.01 \mathrm{~mol} \cdot \mathrm{L}^{-1}$ [14]. To analyse the soil organic matter (SOM) it was used the dry combustion method [15] using the Carbon Analyzer-LECO CN 2000 ${ }^{\circledR}$. Phosphorus (P) and exchangeable cations (CEC) were extracted using the method of cation and anion exchange resin, according to literature [14]. To evaluate the total acidity of the soil, $\mathrm{H}^{+}+\mathrm{Al}^{3+}$ samples were extracted with a $\mathrm{Ca}(\mathrm{OAc})_{2} 1 \mathrm{~N}$ solution of buffered to $\mathrm{pH}$ 7.0, according to the methodology described by EMBRAPA (1997) [16]. Base saturation (BS\%) and aluminium saturation (m) were obtained from calculations. 


\subsection{Statistical Analyses}

Statistical analyses of the data were performed assuming a completely randomised block sampling design, with analysis of variance being performed with the $\mathrm{SAS}{ }^{\circledR}$ statistical model (Statistical Analysis System) version 8.2 for Windows $®$ (SAS, 2010). The averages were compared using the Tukey test at $5 \%$ probability.

\section{Results and Discussion}

Regarding to $\mathrm{pH}$ values in $\mathrm{CaCl}_{2}$ solution, the original soil (untreated control) that received no application of lime and fertilisation, in the surface layer had lower values (4.1) in comparison to the pasture soil which received lime and NPK (4.6 to 5.1) (Table 1). According to the limits established by Sibbald et al. [17] for soils from São Paulo State, Brazil, 31\% of samples presented very high active acidity $\left(\mathrm{pH}_{\mathrm{CaCl}_{2}} \leq 4.3\right.$ ) and $38 \%$ high (4.4 to 5.0 ), $4 \%$ medium (5.1 to 5.5 ) $8 \%$ low (5.6 to 6.0 ) and $19 \%$ very low (>6.0).

Table 1. Values of $\mathrm{pH}$ in $\mathrm{CaCl}_{2}, \mathrm{H}^{+}+\mathrm{Al}^{3+}$ (potential acidity), calcium, magnesium and base saturation (BS\%) of the soil Typic Acrudox cultivated with $U$. brizantha Marandu with a rotational grazing strategy (25 or $35 \mathrm{~cm}$ height) and nitrogen fertilization (50 and $200 \mathrm{~kg} \cdot \mathrm{N} \cdot \mathrm{ha}^{-1}$ ).

\begin{tabular}{|c|c|c|c|c|c|}
\hline \multirow{2}{*}{ Depth (cm) } & \multicolumn{4}{|c|}{ Management adopted (height/nitrogen) } & \multirow{2}{*}{ Untreated control $^{1}$} \\
\hline & $25 / 50$ & $35 / 50$ & $25 / 200$ & $35 / 200$ & \\
\hline \multicolumn{6}{|c|}{$\mathrm{pH}\left(\mathrm{CaCl}_{2}\right)$} \\
\hline $0-5$ & $4.6 \mathrm{aA}$ & $4.7 \mathrm{aA}$ & $4.8 \mathrm{aA}$ & $5.1 \mathrm{Aa}$ & $4.1 \mathrm{Ba}$ \\
\hline $5-10$ & $4.5 \mathrm{aA}$ & $4.5 \mathrm{bA}$ & $4.9 \mathrm{aA}$ & 4.9 Аа & $3.9 \mathrm{Ba}$ \\
\hline $10-20$ & $4.5 \mathrm{aA}$ & $4.2 \mathrm{bA}$ & $4.8 \mathrm{aA}$ & 4.7 Аa & $3.9 \mathrm{Ba}$ \\
\hline $20-30$ & $4.5 \mathrm{aA}$ & $4.3 \mathrm{bA}$ & $4.7 \mathrm{aA}$ & 4.4 Ab & 4.0 Ba \\
\hline $30-40$ & $4.4 \mathrm{aA}$ & $4.0 \mathrm{bA}$ & $4.6 \mathrm{aA}$ & $4.5 \mathrm{Ab}$ & $3.9 \mathrm{Ba}$ \\
\hline \multicolumn{6}{|c|}{$\mathrm{H}^{+}+\mathrm{Al}^{3+}\left(\mathrm{mmol} \cdot \mathrm{dm}^{-3}\right)$} \\
\hline $0-5$ & $45.2 \mathrm{Bc}$ & $47.0 \mathrm{Bc}$ & $38.0 \mathrm{Bb}$ & $38.0 \mathrm{Bc}$ & 47.0 Аа \\
\hline $5-10$ & $49.7 \mathrm{Bbc}$ & $58.0 \mathrm{Bb}$ & $34.0 \mathrm{Bb}$ & $58.0 \mathrm{Ba}$ & $45.0 \mathrm{Ab}$ \\
\hline $10-20$ & $68.0 \mathrm{Aa}$ & $62.0 \mathrm{ABa}$ & $52.0 \mathrm{Ba}$ & $47.0 \mathrm{Bb}$ & $44.0 \mathrm{Ab}$ \\
\hline $20-30$ & $72.0 \mathrm{Aa}$ & 58.0 Аа & $34.0 \mathrm{Bc}$ & 58.0 Aba & $45.0 \mathrm{Ac}$ \\
\hline $30-40$ & $52.0 \mathrm{Ab}$ & $58.0 \mathrm{Ab}$ & $47.0 \mathrm{Aa}$ & $47.0 \mathrm{Ab}$ & 44.0 Ad \\
\hline \multicolumn{6}{|c|}{$\mathrm{Ca}^{2+}\left(\mathrm{mmol} \cdot \mathrm{dm}^{-3}\right)$} \\
\hline $0-5$ & $18.3 \mathrm{aA}$ & $16.0 \mathrm{aA}$ & $18.0 \mathrm{aA}$ & $14.0 \mathrm{aA}$ & $2.0 \mathrm{aB}$ \\
\hline $5-10$ & $11.0 \mathrm{bA}$ & $14.0 \mathrm{aA}$ & $15.0 \mathrm{aA}$ & $11.0 \mathrm{aA}$ & $1.0 \mathrm{aB}$ \\
\hline $10-20$ & $4.0 \mathrm{bAB}$ & $2.0 \mathrm{bB}$ & $8.0 \mathrm{abA}$ & $5.0 \mathrm{bAB}$ & $1.0 \mathrm{aB}$ \\
\hline $20-30$ & $4.0 \mathrm{bAB}$ & $1.0 \mathrm{bB}$ & $8.0 \mathrm{abA}$ & $6.0 \mathrm{abA}$ & $1.0 \mathrm{aB}$ \\
\hline $30-40$ & $3.0 \mathrm{bA}$ & $1.0 \mathrm{bB}$ & $5.0 \mathrm{bAB}$ & $7.0 \mathrm{abA}$ & $1.0 \mathrm{aB}$ \\
\hline \multicolumn{6}{|c|}{$\mathrm{Mg}^{2+}\left(\mathrm{mmol} \cdot \mathrm{dm}^{-3}\right)$} \\
\hline $0-5$ & $9.0 \mathrm{aA}$ & $12.0 \mathrm{aA}$ & $14.0 \mathrm{aA}$ & $12.0 \mathrm{aA}$ & $1.0 \mathrm{aB}$ \\
\hline $5-10$ & $8.0 \mathrm{aA}$ & $6.0 \mathrm{aA}$ & $10.0 \mathrm{aA}$ & $8.0 \mathrm{bA}$ & $0.9 \mathrm{aB}$ \\
\hline $10-20$ & $4.0 \mathrm{bAB}$ & $3.0 \mathrm{bAB}$ & $7.0 \mathrm{abA}$ & $5.0 \mathrm{bAB}$ & $0.9 \mathrm{aB}$ \\
\hline $20-30$ & $2.0 \mathrm{bA}$ & $2.0 \mathrm{bA}$ & $5.0 \mathrm{bA}$ & $4.0 \mathrm{bA}$ & $0.9 \mathrm{aA}$ \\
\hline $30-40$ & $0.9 \mathrm{bA}$ & $1.0 \mathrm{bA}$ & $2.0 \mathrm{bA}$ & $4.0 \mathrm{bA}$ & $0.9 \mathrm{aA}$ \\
\hline \multicolumn{6}{|c|}{ BS (\%) } \\
\hline $0-5$ & $40.1 \mathrm{aA}$ & $40.3 \mathrm{aA}$ & $48.4 \mathrm{aA}$ & $43.5 \mathrm{aA}$ & $4.9 \mathrm{aB}$ \\
\hline $5-10$ & $29.7 \mathrm{aB}$ & $27.1 \mathrm{bB}$ & $46.2 \mathrm{aA}$ & $26.2 \mathrm{abB}$ & $4.0 \mathrm{aC}$ \\
\hline $10-20$ & $11.8 \mathrm{bAB}$ & $8.3 \mathrm{cB}$ & 25.7 bA & $19.2 \mathrm{bAB}$ & $3.3 \mathrm{aB}$ \\
\hline $20-30$ & $8.5 \mathrm{bB}$ & $5.4 \mathrm{cB}$ & 31.3 bA & $15.8 \mathrm{bAB}$ & $3.4 \mathrm{aB}$ \\
\hline $30-40$ & $8.0 \mathrm{bB}$ & $4.8 \mathrm{cB}$ & $16.4 \mathrm{bAB}$ & 20.2 bA & $3.7 \mathrm{aB}$ \\
\hline
\end{tabular}

Values followed by the same letter for each variable do not differ by Tukey's test $(\mathrm{P}<0.05)$; capital letters compare values horizontally, and small letters compare values vertically $(\mathrm{n}=5)^{1}$. Untreated control, original soil without liming and fertilisation. 
Depending on the application of fertilizers and lime on the pasture, there was a trend to increased the $\mathrm{pH}$ in the surface layer (Table 1). For the areas managed at 25/50, 35/50 or 35/200, there were reductions in $\mathrm{pH}$ with depth, showing a superficial action of soil acidity correction, due to lime without incorporation.

The values of potential acidity $\left(\mathrm{H}^{+}+\mathrm{Al}^{3+}\right)$ were in paddocks of the untreated control areas (mean 45.0 mmol $\cdot \mathrm{dm}^{-3}$ ). With lime and soil fertilisation, the values of $\mathrm{H}^{+}+\mathrm{Al}^{3+}$ were reduced to significantly lower values for all management strategies (with average values between 41.0 and $57.4 \mathrm{mmol} \cdot \mathrm{dm}^{-3}$ in the average of each treatment. This fact is possibly attributed to the higher concentration of bases in the surface layer. This acidity was associated with low $\mathrm{pH}$ and concentrations of exchangeable bases (Table 2) with a relationship mean (Pearson's correlation) of $0.96(\mathrm{P}<0.05)$.

The greatest concentrations $(\mathrm{P}<0.05)$ of $\mathrm{Ca}^{2+}, \mathrm{Mg}^{2+}$ and $\mathrm{K}^{+}$, were always found in the surface layers with medium to high values and are the result of liming and application of phosphate and potassium fertiliser at the beginning of the experiment (Tables 1 and 2). These levels were considered medium related to the nutritional requirements of Marandu grass (Werner et al., 1996) [10]. The increased calcium concentration at the surface lower $(0-10 \mathrm{~cm})$ was due to the lime and phosphate fertilisation. However, at 10 to $20 \mathrm{~cm}$ and the deeper, Ca concentrations were lower and similar for all limed and fertilized treatments. For the untreated control, $\mathrm{Ca}, \mathrm{Mg}$ and $\mathrm{K}$ were lower.

Table 2. Values of organic matter (SOM), cation exchange capacity, potassium and phosphorus of the dystrophic Typic Acrudox soil cultivated with $U$. brizantha Marandu with a rotational grazing strategy ( 25 or $35 \mathrm{~cm}$ height) and nitrogen (50 and $200 \mathrm{~kg} \cdot \mathrm{N} \cdot \mathrm{ha}^{-1}$ ) fertilization.

\begin{tabular}{|c|c|c|c|c|c|}
\hline \multirow{2}{*}{ Depth (cm) } & \multicolumn{4}{|c|}{ Management adopted (height/nitrogen) } & \multirow{2}{*}{ Untreated control $^{1}$} \\
\hline & $25 / 50$ & $35 / 50$ & $25 / 200$ & $35 / 200$ & \\
\hline \multicolumn{6}{|c|}{$\mathrm{SOM}\left(\mathrm{g} \cdot \mathrm{dm}^{-3}\right)$} \\
\hline $0-5$ & $59.5 \mathrm{Ba}$ & $62.3 \mathrm{Ba}$ & 83.0 Аа & 81.0 Aa & $28.5 \mathrm{Ca}$ \\
\hline $5-10$ & $35.3 \mathrm{Ab}$ & $36.0 \mathrm{Ab}$ & $38.0 \mathrm{Ab}$ & $40.0 \mathrm{Ab}$ & $17.9 \mathrm{Bb}$ \\
\hline $10-20$ & $30.5 \mathrm{Ab}$ & $31.0 \mathrm{Ab}$ & $29.0 \mathrm{Ac}$ & $30.0 \mathrm{Ac}$ & 15.7 Bb \\
\hline $20-30$ & $25.8 \mathrm{Ac}$ & $27.0 \mathrm{Ac}$ & $22.0 \mathrm{Bd}$ & $28.0 \mathrm{Ac}$ & $11.8 \mathrm{Cc}$ \\
\hline $30-40$ & $23.0 \mathrm{Ac}$ & $24.0 \mathrm{Ac}$ & $22.0 \mathrm{Ad}$ & $22.0 \mathrm{Ad}$ & $10.8 \mathrm{Bc}$ \\
\hline \multicolumn{6}{|c|}{ CEC $\left(\mathrm{mmol} \cdot \mathrm{dm}^{-3}\right)$} \\
\hline $0-5$ & 75.4aA & $78.7 \mathrm{aA}$ & $73.6 \mathrm{aA}$ & $67.2 \mathrm{aA}$ & 53.7 Ba \\
\hline $5-10$ & 70.7 aA & $79.6 \mathrm{aA}$ & $63.2 \mathrm{aA}$ & $78.6 \mathrm{aA}$ & $48.5 \mathrm{Ba}$ \\
\hline $10-20$ & $77.1 \mathrm{aA}$ & 68.1abA & $70 \mathrm{aA}$ & $58.2 \mathrm{bB}$ & 47.4 Ba \\
\hline $20-30$ & 78.7 aA & $62.1 \mathrm{bA}$ & $49.5 \mathrm{bB}$ & $68.9 \mathrm{aA}$ & $48.0 \mathrm{Bb}$ \\
\hline $30-40$ & $56.5 \mathrm{bA}$ & $60.9 \mathrm{bA}$ & $56.2 \mathrm{bA}$ & $58.9 \mathrm{bA}$ & $46.8 \mathrm{Bc}$ \\
\hline \multicolumn{6}{|c|}{ Exchangeable $\mathrm{K}\left(\mathrm{mmol} \cdot \mathrm{dm}^{-3}\right)$} \\
\hline $0-5$ & $2.9 \mathrm{ABa}$ & $3.7 \mathrm{Aa}$ & 3.6 Аа & $3.2 \mathrm{ABa}$ & $2.1 \mathrm{Ba}$ \\
\hline $5-10$ & $2.0 \mathrm{Ba}$ & $1.6 \mathrm{Bb}$ & 4.2 Аа & $1.6 \mathrm{Bb}$ & $1.8 \mathrm{Ba}$ \\
\hline $10-20$ & $1.1 \mathrm{Bb}$ & $1.5 \mathrm{Bb}$ & 3.0 Аа & $1.2 \mathrm{Bb}$ & 1.1 Bab \\
\hline $20-30$ & $0.7 \mathrm{Bb}$ & $1.1 \mathrm{Bb}$ & $2.5 \mathrm{Ab}$ & $0.9 \mathrm{Ab}$ & $0.9 \mathrm{Bb}$ \\
\hline $30-40$ & $0.6 \mathrm{Bb}$ & $0.9 \mathrm{Bb}$ & $2.2 \mathrm{Ab}$ & $0.9 \mathrm{Ab}$ & $0.9 \mathrm{Bb}$ \\
\hline \multicolumn{6}{|c|}{ Available P (mg $\left.\cdot \mathrm{dm}^{-3}\right)$} \\
\hline $0-5$ & 15.0 Аа & 14.0 Аа & 16.0 Аа & $13.0 \mathrm{Ba}$ & $3.1 \mathrm{Ca}$ \\
\hline $5-10$ & $6.0 \mathrm{Ab}$ & $5.0 \mathrm{Ab}$ & $5.0 \mathrm{Ab}$ & $5.0 \mathrm{Ab}$ & $3.9 \mathrm{Ba}$ \\
\hline $10-20$ & $4.0 \mathrm{Ab}$ & $3.0 \mathrm{Ab}$ & $4.0 \mathrm{Ab}$ & $4.0 \mathrm{Ab}$ & $2.5 \mathrm{Aa}$ \\
\hline $20-30$ & $3.0 \mathrm{Ab}$ & $3.0 \mathrm{Ab}$ & $3.0 \mathrm{Ab}$ & $3.0 \mathrm{Ab}$ & $2.1 \mathrm{Aa}$ \\
\hline $30-40$ & $4.0 \mathrm{Ab}$ & $5.0 \mathrm{Ab}$ & $4.0 \mathrm{Ab}$ & $5.0 \mathrm{Ab}$ & $2.1 \mathrm{Ba}$ \\
\hline
\end{tabular}

Values followed by the same letter for each variable do not differ by Tukey’s test $(\mathrm{P}<0.05)$; capital letters compare values horizontally, and small letters compare values vertically $(n=5)^{1}$. Untreated control, original soil without liming and fertilisation. 
As other studies have shown [18] [19] the buffering characteristics of soil organic matter and/or increasing the ionic strength of the soil solution due to the increase in $\mathrm{Ca}, \mathrm{Mg}$ and $\mathrm{K}$ contents to liming resulted in higher $\mathrm{pH}$ values. Only in the area managed at 35/50 or 35/200 were reductions in $\mathrm{pH}$ with depth, showing a superficial process of soil acidity correction. There were positive correlations between $\mathrm{Ca}(0.70), \mathrm{Mg}(0.70), \mathrm{K}(0.45)$, BS $(0.73)$ and soil $\mathrm{pH}$, and a negative correlation between aluminium saturation $(-0.77)$ showing the importance on soil reaction on the soil fertility and the conditions for forage production. The chemical properties values (Table 1 and Figure 1) were similar to those obtained by Pavan and Abreu Jr. and Muraoka [20] [21].

The $\mathrm{Al}$ saturation index was high in the untreated control area (without fertilisation management) showing average values of $75.9 \%$ which is detrimental to the growth of Urochloa brizantha cv. Marandu (Figure 1).

In fact, the importance of aluminium as a factor in soil acidity and highly weathered tropical acid is evident. The contents of exchangeable $\mathrm{Al}$ in the soil of the untreated control pastures and from depths of between 0 - 5 $\mathrm{cm}$ and 5 - $10 \mathrm{~cm}$ were considered high $\left(16.4 \mathrm{mmol} \cdot \mathrm{dm}^{-3}\right)$, according to Abreu Jr. and Muraoka [21] and similar between those depths. In acid mineral soils of tropical climate regions, the high aluminium content, associated to high acidity and low fertility, it is one of the main constraints for agricultural production. However the action of lime, only at one surface layer $\left(0-5 \mathrm{~cm}\right.$ ) decrease $\mathrm{Al}$ for values of $2.3 \mathrm{mmol} \cdot \mathrm{dm}^{-3}$ (with $\mathrm{Al}$ saturation from 3,2 to $10.1 \%$ ), values considered low and not phytotoxic to Marandu grass, and associated to $\mathrm{pH}$ values ranged from 4.6 to 5.1 .

After adopting strategic management and correct fertilisation, the surface and beneficial action of lime in the neutralisation of aluminium and reduction in total acidity is evident. However, the selection and use of grasses better adapted to the stress of fertility is increasingly recommended, including the selection and introduction of new genotypes of forage, such as hybrids of $U$. brizantha $\mathrm{x} U$. ruziziensis that can be able to survive and produce Al-resistance, which tolerate high grazing pressures and enable higher stocking rates per hectare [22]. With the correction of $\mathrm{pH}$ and exchangeable aluminium, the phosphorus was adapted to withstand levels of enhancement in livestock in the proposed system.

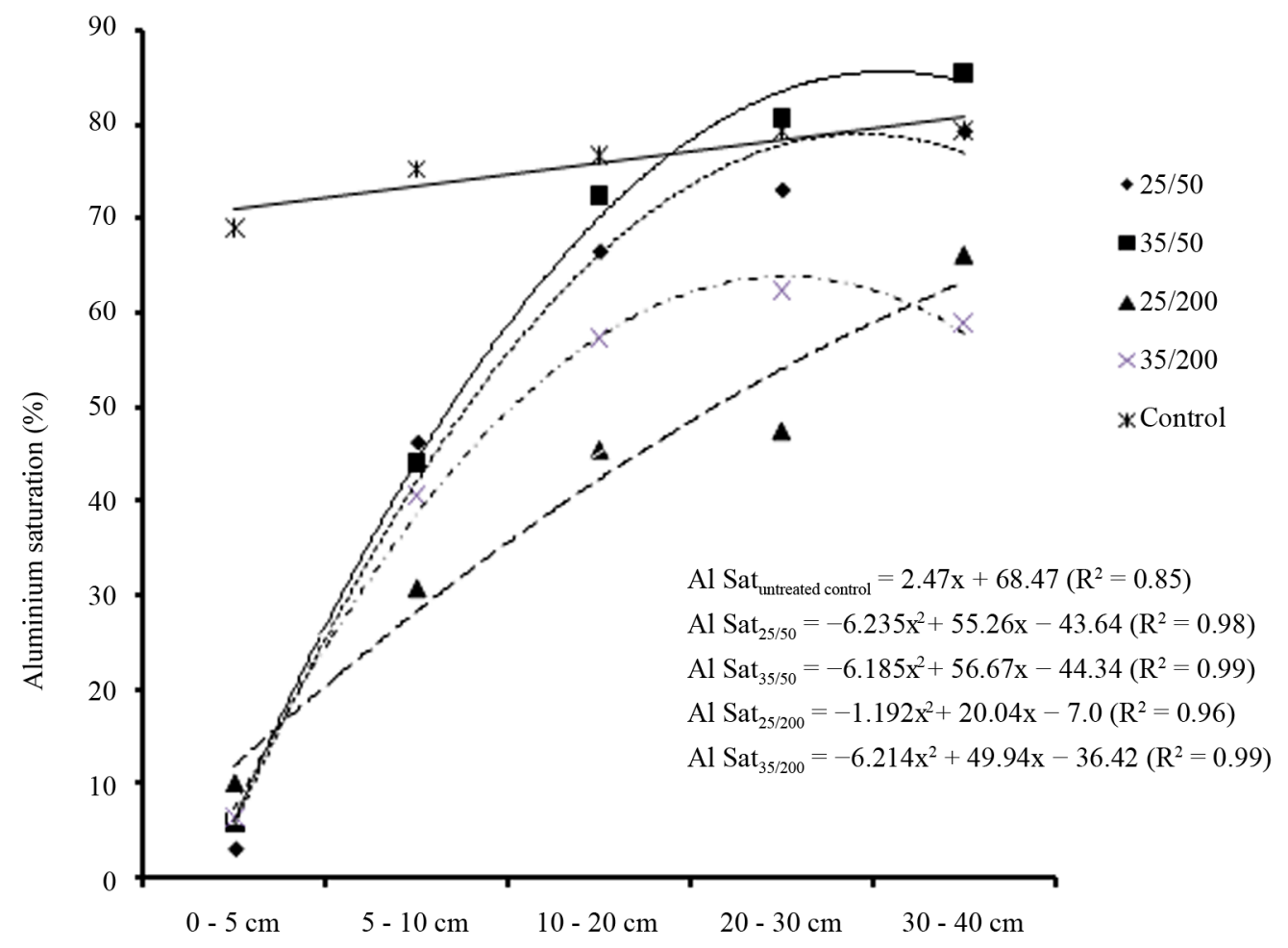

Layer depth

Figure 1. Aluminium saturation in the Typic Acrudox soil cultivated with $U$. brizantha Marandu with a rotational grazing strategy ( 25 or $35 \mathrm{~cm}$ height) and nitrogen fertilization (50 and $200 \mathrm{~kg} \cdot \mathrm{N} \cdot \mathrm{ha}{ }^{-1}$ ) in five soil layers $(0-5,5-10,10-20,20-30$ and $30-40 \mathrm{~cm})$. 
The observed increase in Ca, Mg and base saturation and reduction in the percentage of exchangeable $\mathrm{Al}$ and $\mathrm{Al}$ saturation in the surface layer represent improvements in soil fertility, which resulted in productivity in the pasture Marandu grass. However, the levels of $\mathrm{Ca}+\mathrm{Mg}$, K stood near the critical level one year after application. The extraction and removal of nutrients from the system, either by grazing or via body livestock composition, indicates future limitations and adoption of a strategy for management of soil fertility, such as adding large quantities of limestone. To work around this fact, calculus of recommended amounts of limestone, an additional factor can be included (1.5 or 2.0) that considers the buffering capacity of the soil to increase and maintain the soil quality for a longer time and obtain a better yield of pasture and the animal productivity. Thus, the effects of liming would be more extendable and would not require annual applications of lime.

The value of base saturation index of the soil in the surface layers is larger because these areas received the limestone (calcium and magnesium) without incorporation by topdressing the potassium and phosphate fertilisers. The indices of base saturation on the surface $(5 \mathrm{~cm})$ were very close to the proposed $50 \%$, with average values of $43 \%$ due to low mobility of calcium and magnesium in the soil.

There was a greater accumulation of surface organic matter (Table 2). Note that the increased accumulation of surface organic matter was with the application of nitrogen (from 50 to $200 \mathrm{~kg} \cdot \mathrm{N} \cdot \mathrm{ha}{ }^{-1}$ ). The content of organic matter in the surface layer of $0-5 \mathrm{~cm}$ was higher with nitrogen fertilisation of $200 \mathrm{~kg} \cdot \mathrm{N} \cdot \mathrm{ha}^{-1}$ in comparison to $50 \mathrm{~kg} \cdot \mathrm{ha}^{-1} \cdot \mathrm{N}$. However, the contents of organic matter in this layer were similar between the sward height managements $(25$ or $35 \mathrm{~cm}$ ) within the two levels of fertilisation, but with good contents in all combinations. Without the management strategies and fertilisation, the accumulation of organic matter was lower in the untreated control $\left(<34.0 \mathrm{~g} \cdot \mathrm{dm}^{-3}\right)$, a level below those viewed as critical. For all the treatments, deeper soil layers showed lower concentrations of total organic matter $(\mathrm{SOM}=\mathrm{C} \times 1.723)$.

Our results are consistent with studies conducted by Oliveira and col. [23] who's observed values organic matter that were significantly higher in surface layers compared to deeper layers. Kemper and Kock [24] indicated that many soils in the Western United States and Canada suffered significant decline in structural stability when the soil organic carbon (SOC) was below 2\%. Similarly, Greenland and col. [25] concluded that soils in England and Wales with $<2 \%$ SOC were contents with structural deterioration. However, this $2 \%$ threshold was a "rule of thumb" (sic) to indicate soil structural stability, not a measure of the soil's physical properties in the field. Nevertheless, this value of $2 \%$ SOC (equivalent to ca. 3.4\% SOM) is a critical threshold of soil quality. In tropical soils the organic matter have a faster turnover than temperate soils, due to enhanced decomposition under the higher moisture and temperature regime of the tropics [26] [27] attributed the soil C increase subjected to more conservation tillage systems, similar to pasture, to two main factors: 1) physical protection of the organic compounds against microbial decomposition, favored by the $\mathrm{C}$ occlusion in the soil aggregates; and 2) chemical protection of organic compounds through their interaction with minerals and cations, which hinders their decomposition. SOM values varying from $2.7 \%$ to $8.4 \%$ were described by several authors in tropical conditions [28] [29].

The strategy of amending and fertilising in established pastures increased the content of organic matter, mainly in the surface layers. The application of $200 \mathrm{~kg} \cdot \mathrm{N} \cdot \mathrm{ha}^{-1}$ has higher forage accumulation per year of 23.000 $\mathrm{kg} \cdot \mathrm{ha}^{-1}$ of DM than to $50 \mathrm{~kg} \cdot \mathrm{N} \cdot \mathrm{ha}^{-1}$ with $15.200 \mathrm{~kg} \cdot \mathrm{ha}^{-1}$ of DM, while for untreated control accumulated 8.800 $\mathrm{kg} \cdot \mathrm{ha}^{-1}$ of DM. Grazing losses were 24.1 and $20.3 \%$ for treatments of 200 and $50 \mathrm{~kg} \cdot \mathrm{N} \cdot \mathrm{ha}{ }^{-1}$ [12], which has favoured the return of higher herbage dry mass to the soil, increasing the accumulation of soil organic matter. The SOM soil in surface layer was on average $60.9 \mathrm{~g} \cdot \mathrm{dm}^{-3}$ and $82.0 \mathrm{~g} \cdot \mathrm{dm}^{-3}$ that were found under application of 50 or $200 \mathrm{~kg} \cdot \mathrm{N} \cdot \mathrm{ha}^{-1}$ and the untreated control $28.5 \mathrm{~g} \cdot \mathrm{dm}^{-3}$ (Table 2).

In grazing conditions, the losses were greater in grassland managed at $35 \mathrm{~cm}(24.1 \%)$ than in the ones grazed at $25 \mathrm{~cm}$ (20.3\%) of pre-grazing height [12], where more organic matter was added to the soil surface from pre-grazing heights of $35 \mathrm{~cm}$. The increases (\%) in the soil organic matter, for average values, were $106 \%$ and $113 \%$ for treatments $25 / 50$ and $35 / 50$, respectively, but were $115 \%$ and $127 \%$ for treatments of $25 / 200$ and $35 / 200$ respectively, in comparison to the untreated control.

A meta-analysis of 115 studies in pastures and other grazing lands worldwide [30] indicated that $C$ soil levels increased with improved management (primarily fertilisation, grazing management, and conversion form cultivation or native vegetation, improved grass species) in $75 \%$ of the studies considered [31].

According to Loveland and Webb [32] the debate on SOM will continue, if for no other reason than almost everyone sees it as a keystone indicator for soil quality. However, the nature of this indicator (e.g., total SOM or SOC, "active" SOM or some fraction of it) will require further investigation if it is to be widely accepted in the 
long term, with parallel implications for design, implementation and costs of soil monitoring frameworks.

The CEC had variation with the soil depth $(0-30 \mathrm{~cm})$ varying from 46.8 to $79.6 \mathrm{mmol} \cdot \mathrm{dm}^{-3}$ of soil but decreased in the deeper layers (30 to $40 \mathrm{~cm}$ ) varying from 56.5 to 58.9 (Table 2).

The statistical analyses showed the differences between the untreated control and CEC soil average 48.9, that were lower than the other treatments 25/50; 35/50; 25/200 and 35/200, that averaged 71.7; 69.9; 62.5 and 66.4 respectively.

For pastures fertilised and lime, the CEC was highly occupied by basic cations. In addition, the increase of the CEC in the surface layer can be attributed to increased soil organic matter. Soil CEC may increase with increasing $\mathrm{pH}$ and by adding phosphate [33]. Hence, the CEC comprises a permanent (CECp) and variable (pH dependent) fraction (CECv). CECp has been regarded as derived primarily from the clay fraction. In the untreated control area (i.e., without management) the CEC values were lower, primarily due to higher values in potential acidity $\left(\mathrm{H}^{+}+\mathrm{Al}^{3+}\right)$, which is not interesting for the cultivation of Marandu grass.

It was found that phosphorus levels were higher only in the surface layer of the treatments that received phosphorus at the beginning of the experimental work, although the results are not considered high. The best yield outcomes are achieved when lime applications are combined with phosphate fertilisation in pasture systems [2], which primarily aims at improving soil quality, by raising the $\mathrm{pH}$, the nutrients' availability and recovery is increased, as is the case with $\mathrm{P}$, for example.

From this layer down, the levels of available $\mathrm{P}$ were lower $(\mathrm{P}<0.05)$, which is considered low and similar for all layers. In the original soil (untreated control), the $\mathrm{P}$ levels were very low $(\mathrm{P}<0.05)$ in comparison to the pasture fertilised soils and did not vary significantly with depth. Higher levels of $\mathrm{P}$ in the surface layer were expected, particularly in the absence of soil tillage and addition of plant materials, with the topdressing application of phosphate fertiliser and higher $\mathrm{pH}$ values (Table 2).

The original soil (without lime and/fertilisation — untreated control) showed relationships between cations and the CEC that were below the ideal range, which can be considered a nutritional imbalance. These results indicate that there were limitations in partial nutrients for proper growth and nutrition of the pasture, although the nutritional requirements of Marandu grass are lower when compared with other forage plants, such as those in the genus Panicum [34].

Applying the phosphate fertiliser and lime in topdressing resulted higher $\mathrm{pH}$ and $\mathrm{P}$ contents in the surface layer. In the deeper layers, the $\mathrm{P}$ levels were low because $\mathrm{P}$ is not a mobile nutrient in soil [35] and was not incorporated into the soil. Additionally, the $\mathrm{P}$ immobilisation by $\mathrm{Fe}$ and $\mathrm{Al}$ oxides and consequently, low availability [36].

The situation of Brazilian pastures often includes fodder production in soils of low fertility, which certainly implies a reduction of the pasture productivity potential, even when dealing with species of the genus Urochloa, which is considered rustic. To recover pastures, the adoption of corrective strategies, such as liming practices associated with economic management has proven feasible for phosphorus and other nutrients to maintain or increase productivity in pasture areas.

Gimenes et al. [11] found that applying $50 \mathrm{~kg} \cdot \mathrm{N} \cdot \mathrm{ha}^{-1}$ in comparison to $200 \mathrm{~kg} \cdot \mathrm{ha}^{-1}$, there were increases in: 1) the percentage of leaves in the forage mass of Marandu grass after grazing (11.9\% to 15.6\%); 2 ) the herbage accumulation rate (29.1 to $\left.51.9 \mathrm{~kg} \cdot \mathrm{ha}^{-1} \cdot \mathrm{day}^{-1}\right)$; and 3) the stocking rate (2.55 to 3.44 animal unit $\cdot \mathrm{ha}^{-1}$, animal unit $=450 \mathrm{~kg}$ live weight), leading to a weight gain-GP, (697 and $863 \mathrm{~kg} \cdot \mathrm{ha}^{-1}$, at 35 and $25 \mathrm{~cm}$ of pre-grazing height). Only variations in the grazing management strategy resulted in a 31\% increase in live weight gain, up from approximately $24 \%$ resulting from the application of $\mathrm{N}$, which emphasis the importance of proper grazing management and lime plus fertilization, as a way to increase animal performance and productivity of the system.

In this context, the use of nitrogen fertilisers applied fractionally is a way that increases in the dry biomass of forages, which can result in increase on animal production, allowing enhancements in stocking rates and resulting in improved animal productivity, $\mathrm{kg} \cdot \mathrm{ha}^{-1}[6][11]$.

\section{Conclusions}

Intensive livestock systems (rotational stocking), lime and fertiliser application (NPK) must be monitored to prevent nutritional restrictions of soil fertility common in tropical soils so that subclinical levels of nutrients do not limit the productivity of pastures. It is interesting to highlight that the liming and fertilisation can influence the soil chemical properties and improve the soil fertility (reduce high acidity, aluminium saturation and increase 
exchangeable bases), and it promotes the higher forage accumulation of Marandu grass. Without adopting those practices, the forage yields and animal production are limited. In our study, higher accumulation rates of SOM were found with Marandu grass fertilized with $200 \mathrm{~kg} \cdot \mathrm{N} / \mathrm{ha}$ than $50 \mathrm{~kg} \cdot \mathrm{N} / \mathrm{ha}$, due to elevated surplus forage not consumed by grazing. The contents of organic matter in surface layer were similar between the sward height managements $(25$ or $35 \mathrm{~cm}$ ) within the two levels of fertilisation, but with good contents in all combinations. The management practice for the pre-grazing height of $25 \mathrm{~cm}$, regardless of the nitrogen application, is the best strategy to soil quality and livestock production.

\section{Acknowledgements}

This project was financed by Institute of Animal Science and Pastures, APTA/SP and Matsuda Seeds and Animal Mineral Nutrition.

\section{References}

[1] Instituto Brasileiro de Geografia e Estatística (2013). http://www.ibge.gov.br

[2] Scott, D. (2000) Fertilizer and Grazing Rejuvenation of Fescue Tussock Grassland. New Zealand Journal Agricultural Research, 43, 481-490. http://dx.doi.org/10.1080/00288233.2000.9513444

[3] Peters, M., Franco, L.H., Schmidt, A. and Hincapié, B. (2001) Especies forrajeras multiproposito: Opciones para productores de Centroamérica. CIAT Publication, Cali.

[4] Alexandrino, E., Nascimento Jr., D., Mosquim, P.R., Regazzi, A.J. and Rocha, F.C. (2004) Características morfogênicas e estruturais na rebrotação da Brachiaria brizantha cv. Marandu submetida a três doses de nitrogênio. Revista Brasileira de Zootecnia, 33, 1372-1379.

[5] Cadish, G., Schunke, R.M. and Giller, K.E. (1994) Nitrogen Cycling in a Pure Grass Pasture and a Grass-Legume Misture on a Red Latosol in Brazil. Tropical Grasslands, 28, 43-52.

[6] Oliveira, P.P.A., Trivelin, P.C.O., Oliveira, W.S. and Corsi, M. (2005) Fertilização com N e S na recuperação de pastagem de Brachiaria brizantha cv. Marandu em Neossolo Quartzarênico. Revista Brasileira de Zootecnia, 34, 11211129. http://dx.doi.org/10.1590/S1516-35982005000400005

[7] Sibbald, A.R., Marriot, C.A., Agnew, R.D.M. and Dalziel, A.J.I. (2004) The Implications of Controlling Grazing Swards Height for the Operation and Productivity of Upland Sheep Systems in UK: 7. Sustainability of White Clover in Grass/Clover Swards with Reduced Levels of Fertilizer Nitrogen. Grass and Forage Science, 59, 264-273. http://dx.doi.org/10.1111/j.1365-2494.2004.00426.x

[8] Haynes, R.J. and Williamas, P.H. (1993) Nutrient Cycling and Soil Fertility in the Grazed Pasture Ecosystem. Advances in Agronomy, 49, 119-199. http://dx.doi.org/10.1016/S0065-2113(08)60794-4

[9] Costa, D.F.A. (2007) Respostas de bovinos de corte à suplementação energética em pastos de capim-marandu submetidos a intensidades de pastejo rotativo durante o verão. Dissertação (Mestrado em Ciência Animal e Pastagens) —Escola Superior de Agricultura “Luiz de Queiroz”, Universidade de São Paulo, Piracicaba, 98p.

[10] Werner, J.C., Paulino, V.T., Cantarella, H., Andrade, N.O. and Quaggio, J.A. (1996) Forrageiras. In: Van Raij, B., Cantarella, H., Quaggio, J.A. and Furlani, A.M.C., Eds., Recomendações de adubação e calagem para o Estado de São Paulo, 2nd Edition, Instituto Agronomico, Campinas, 263-273.

[11] Gimenes, F.M.A., Da Silva, S.C., Fialho, C.A., Gomes, M.B., Berndt, A., Gerdes, L. and Colozza, M.T. (2011) Ganho de peso e produtividade animal em capim-marandu sob pastejo rotativo e adubação nitrogenada. Pesquisa Agropecuária Brasileira, 46, 751-759. http://dx.doi.org/10.1590/S0100-204X2012000600006

[12] Tan, K.H. and Dowling, P.S. (1984) Effect of Organic Matter on CEC Due to Permanent and Variable Changes in Selected Temperate Region Soils. Geoderma, 32, 89-101. http://dx.doi.org/10.1016/0016-7061(84)90065-X

[13] Barthram, G.T. (1985) Experimental Techniques: The HFRO Sward Stick. In: The Hill Farming Research Organization. Biennial Report, HFRO, Midlothian, 29-30.

[14] Van Raij, B., Andrade, J.C., Cantarella, H. and Quaggio, J.A. (2001) Análise química para avaliação da fertilidade de solos tropicais. Instituto Agronômico, Campinas, 285p.

[15] Nelson, D.W. and Sommers, L.E. (1996) Total Carbon, Organic Carbon, and Organic Matter. In: Black, C.A., Ed., Methods of Soil Analysis. Part 3. Chemical Methods, Soil Science of America and American Society of Agronomy, Madison, 961-1010.

[16] Embrapa (1997) Centro Nacional de Pesquisa de Solos. Manual de métodos de análise de solo. 2nd Edition, Embrapa, Rio de Janeiro, 212p. 
[17] Van Raij, B., Quaggio, J.A., Cantarella, H., Ferreira, M.E. and Lopes, A.S. (1987) Análise química do solo para fins de fertilidade. Fundação Cargill, Campinas, 170p.

[18] Muzzilli, O. (1983) Influencia do sistema de plantio direto, comparado ao convencional, sobre a fertilidade da camada arável do solo. Revista Brasileira de Ciência do Solo, 7, 95-102.

[19] Franchini, E.J.C., Malavolta, E., Miyzawa, M. and Pavan, M.A. (1999) Alterações químicas em solos ácidos de resíduos vegetais. Revista Brasileira de Ciência do Solo, 23, 533-542.

[20] Pavan, M.A. (1983) Alumínio em solos ácidos do Paraná: relação entre alumínio não-trocável, trocável e solúvel, com o pH, CTC, porcentagem de saturação de Al e matéria orgânica. Revista Brasileira de Ciência do Solo, 7, 39-46.

[21] Abreu Jr., C.H., Muraoka, T. and Lavorante, A.F. (2003) Lavorante Exchangeable aluminium evaluation in acid soils. Scientia Agrícola, 60, 543-548.

[22] Rao, I.M., Miles, J.W. and Ricaurte, J. (2006) Seleccion de híbridos de Brachiaria com resistência al alumínio. Pasturas Tropicales, $\mathbf{2 8}, \mathbf{2 0 - 2 5 .}$

[23] Oliveira, G.C., Dias Jr., M.S., Resck, D.V.S. and Curi, N. (2004) Caracterização química e física-hídrica de um Latossolo Vermelho após vinte anos de manejo e cultivo do solo. Revista Brasileira de Ciência do Solo, 28, 327-336. http://dx.doi.org/10.1590/S0100-06832004000200011

[24] Kemper, W.D. and Koch, E.J. (1966) Aggregate Stability of Soils from Western United States and Canada. USDA Technical Bulletin, Washington DC.

[25] Greenland, D.J., Rimmer, D. and Payne, D. (1975) Determination of the Structural Stability Class of English and Welsh Soils, Using a Water Coherence Test. Journal of Soil Science, 26, 294-303. http://dx.doi.org/10.1111/j.1365-2389.1975.tb01953.x

[26] Six, J., Feller, C., Denef, K., Ogle, S.M., Sá, J.C.M. and Albrecht, A. (2002) Soil Organic Matter, Biota and Aggregation in Temperate and Tropical Soils: Effects of No-Tillage. Agronomie, 22, 755-775. http://dx.doi.org/10.1051/agro:2002043

[27] Paul, E.A. and Clark, F.E. (1989) Soil Microbiology and Biochemistry. Academic Press, San Diego, 272p.

[28] Siqueira Neto, M., Scopel, E., Corbeels, M., Cardoso, A.N., Douzet, J.M., Feller, C., Piccolo, M.C., Cerri, C.C. and Bernoux, M. (2010) Soil Carbon Stocks under No-Tillage Mulch-Based Cropping Systems in the Brazilian Cerrado: An On-Farm Synchronic Assessment. Soil Tillage Research, 110, 187-195. http://www.sciencedirect.com/science/article/pii/S0167198710001352

[29] Trindade, J.K., Da Silva, S.C., Souza Jr., S.J., Giacomini, A.A., Zeferino, C.V., Guarda, V.D. and Carvalho, P.C.F. (2007) Composição morfológica da forragem consumida por bovinos de corte durante o rebaixamento do capimmarandu submetido a estratégias de pastejo rotativo. Pesquisa Agropecuária Brasileira, 42, 883-890. http://dx.doi.org/10.1590/S0100-204X2007000600016

[30] Conant, R.T., Paustin, K. and Elliot, E.T. (2001) Grassland Management and Conversion into Grassland: Effects on Soil Carbon. Ecological Applications, 11, 343-355. http://dx.doi.org/10.1890/1051-0761(2001)011[0343:GMACIG]2.0.CO;2

[31] Soussana, J.F., Tallec, T. and Blanfort, V. (2010) Mitigating the Greenhouse Gas Balance of Ruminant Production Systems through Carbon Sequestration in Grassland. Animal, 4, 334-350. http://dx.doi.org/10.1017/S1751731109990784

[32] Loveland, P. and Webb, J. (2003) Is There Critical Level of Organic Matter in the Agricultural Soils of Temperate Regions: Review. Soil Tillage Research, 70, 1-18. http://dx.doi.org/10.1016/S0167-1987(02)00139-3

[33] Tan, K.H. and Dowling, P.S. (1984) Effect of Organic Matter on CEC Due to Permanent and Variable Changes in Selected Temperate Region Soils. Geoderma, 32, 89-101. http://dx.doi.org/10.1016/0016-7061(84)90065-X

[34] Viani, R.A.G., Rodrigues, R.R., Dawson, E.T. and Oliveira, R.S. (2011) Savanna Soil Fertility Limits Growth But Not Survival of Tropical Forest Tree Seedlings. Plant and Soil, 349, 341-353. http://link.springer.com/article/10.1007\%2Fs11104-011-0879-7

[35] Falleiro, R.M., Souza, C.M., Silva, C.S.W., Sediyama, C.S., Silva, A.A. and Fagundes, J.L. (2003) Influência dos sistemas de preparo nas propriedades químicas e físicas do solo. Revista Brasileira Ciência do Solo, 27, 1097-1104.

[36] Addiscot, T.M. and Thomas, D. (2000) Tillage, Mineralization and Leaching: Phosphate. Soil Tillage Research, 53, 255-273. http://dx.doi.org/10.1016/S0167-1987(99)00110-5 